\title{
Going digital: Back to the future
}

Written by: Andy Wyckoff, Director, OECD Directorate for Science, Technology and Innovation

Last update: 7 March 2019

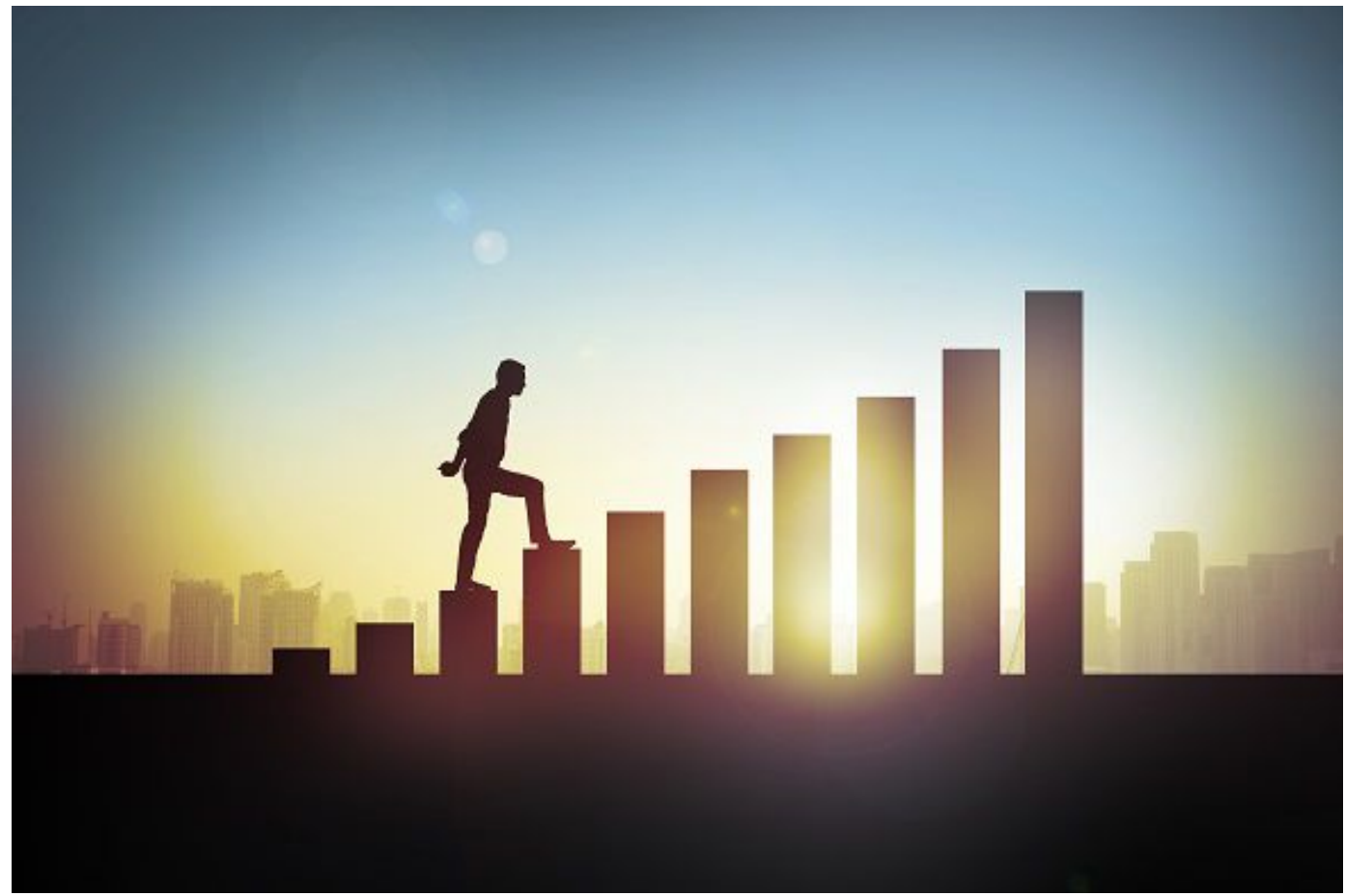

Two decades ago the OECD held its first international ministerial meeting on the digital economy. A lot has changed since then, but some old challenges persist while new ones have emerged. Food for thought as we embark on the next 20 years and prepare for the transformative effects of the digital economy.

Do you remember the first thing you ever bought, or sold, online? As we have already been living in the digital economy for an entire generation, many of us would probably have to think back a long way. In fact, it was just over 20 years ago in Ottawa, on 7-9 October 1998, when the OECD together with the Canadian government held the first international ministerial meeting on electronic commerce, which was shorthand for what we now call the digital economy. It is worth revisiting as we embark on the OECD Summit on Going Digital, 11-12 March 2019. 
Electronic commerce was, of course, a radically new way of doing business then, and it continues to evolve to this day. It was clear in 1998 that e-commerce would be potentially a major engine for economic growth and development around the world. But the rapidly growing digital marketplace needed some ground rules, which called for both a shared vision and a higher level of co-operation among all players-businesses, consumers, the technical community, policymakers, regulators, and more-an approach that has come to be labelled as "multistakeholder".

It is worth recalling that in 1998 Google was in its infancy and Facebook, YouTube and Twitter were still a long way off. Apple was near bankruptcy. Many mobile phones still sported visible antennas and the price of internet access was steep. The Ottawa Ministerial Meeting's title was “A borderless world: Realising the potential of global electronic commerce", which may sound a bit old-fashioned to us now. However, the issues on the agenda, including infrastructure, taxation, disruption, social impact and trust, have come to frame the digital policy debates of today. And funnily enough we are again talking about e-commerce, with some 76 countries and regions agreeing in Davos in January to work on a WTO agenda for negotiations on new e-commerce rules for the 21st century.

The word "borderless" was of the essence in that heady time of globalisation. New conventions and procedures became necessary, not only insofar as consumers could now buy goods and services across different jurisdictions, but also as existing policies and regulations applied to a much more traditional definition of commerce. Individual countries faced challenges in addressing these issues effectively on their own. The global reach of e-commerce called for both an international and a multi-stakeholder approach. Indeed, Ottawa broke new ground for the OECD as it was our first ministerial meeting where member countries invited international organisations, business, labour, and consumer and public interest groups to participate.

An ambitious Ottawa agenda revolved around four main themes, which echo loudly today: building trust; ensuring effective protection and removing unnecessary barriers; enhancing information infrastructure; and developing a clear understanding of social and economic impacts in order to maximise the benefits of a transition to a digital economy. It not only laid the groundwork for global multi-stakeholder co-operation, but helped set the stage for the further development of the information society. In addition, a global action plan for electronic commerce prepared by business with recommendations to governments was on the table, as well as a report on the role of international and regional bodies.

The Ottawa meeting delivered concrete results. It gave rise to three ministerial declarations, which at their heart aimed to help foster consumer trust and protection in the uptake and continued use of e-commerce: 
- Declaration on the Protection of Privacy on Global Networks: Ministers called upon the OECD to provide practical guidance for the implementation of its 1980 OECD privacy guidelines in an online environment, based on national experiences. Updated in 2013, the privacy guidelines http://www.oecd.org/ internet/ieconomy/privacy-guidelines.htm are still a popular resource today.

- Declaration on Consumer Protection in the Context of Electronic Commerce: Digital literacy and encouraging the development of technology as a tool for protecting consumers are still at the heart of building trust in e-commerce to this day. The OECD went on to produce its Guidelines for Consumer Protection in the context of Electronic Commerce in 1999, with an update in 2016. http://www.oecd.org/sti/consumer/

oecdguidelinesforconsumerprotectioninthecontextofelectroniccommerce199 9.htm

- Declaration on Authentication for Electronic Commerce: Ministers reaffirmed the objectives set forth in the OECD 1985 Declaration on Transborder Data Flows and its 1997 Recommendation on Guidelines for Cryptography Policy. https://legalinstruments.oecd.org/public/doc/108/108.en.pdf

An excellent 1999 article summarising the issues is still available online (although you will need to excuse a few broken URLs in the text). It makes for an interesting read today as we can reflect on how the issues have matured over the past 20 years and how many developments we saw coming, and how many we didn't, including social media and the rise of data as a driver of innovation. But with every innovation, at least we had acquired experience in how to respond.

The OECD has worked tirelessly on digital economy issues ever since those early days. This work reached a turning point with the Seoul Ministerial on the Future of the Internet Economy in 2008, just a year after the iPhone was first launched. This meeting "considered the social, economic and technological trends shaping the development of the internet and looked at its potential to evolve from a useful platform to an essential infrastructure for all economic and social sectors". In other words, the digital economy was the economy. In the lead-up to Seoul, OECD Secretary-General Angel Gurría followed the new participative and social web trend by calling on "YouTubers" to contribute their thoughts on how they believed the internet could make the world a better place. Moreover, an interview in an OECD Observer special edition to the Seoul event even evoked the promise of a very new microblog called Twitter.

In 2016, with digitalisation having permeated the world economy, the OECD Cancún Ministerial on the Digital Economy: Innovation, Growth and Social Prosperity marked another pivotal point with the Cancún Ministerial Declaration and a focus on internet openness, digital trust, global connectivity, and jobs and skills.

A generation has passed since electronic commerce broke through the traditional boundaries of government departments, national borders and industry sectors 
and called for truly cross-cutting solutions involving everyone. Now with the rapid and at times unpredictable nature of the digital transformation, it is very apparent that our institutions for policymaking are facing important challenges. The OECD Going Digital project is redefining how we think about digital policy and delivering a new policy framework, including a new toolkit, to help governments and citizens harness the promise of digital technologies for growth and wellbeing, and reduce any risks too. Our Going Digital Summit in March 2019 marks another milestone in this remarkable journey of digital transformation. Here's to the next 20 years.

@OOECD Observer No 317 Q1 2019

\section{References}

OECD Going Digital project at www.oecd.org/going-digital www.oecd.org/goingdigital

OECD Going Digital Toolkit at www.oecd.org/going-digital-toolkit www.oecd.org/going-digital-toolkit

OECD (2019), Going Digital: Shaping Policies, Improving Lives, OECD Publishing, Paris, http://dx.doi.org/https://doi.org/10.1787/9789264312012-en.

OECD (2019), Measuring the Digital Transformation: A Roadmap for the Future, OECD Publishing, Paris, http://dx.doi.org/ https://doi.org/

10.1787/9789264311992-en

OECD (2019), "Trade in the Digital Era”, OECD Going Digital Policy Note, OECD, Paris, http://www.oecd.org/going-digital/trade-in-the-digital-era.pdf

ECD (2019), "Unlocking the potential of e-commerce", OECD Going Digital Policy Note, OECD, Paris, www.oecd.org/going-digital/unlocking-the-potential-of-ecommerce.pdf www.oecd.org/going-digital/unlocking-the-potential-of-ecommerce.pdf

Ottawa conference proceedings | Conclusions and Ministerial Declarations, available at www.oecd.org www.oecd.org

The Internet Economy on the Rise: Progress since the Seoul Declaration, see www.oecd.org/internet/internet-economy-on-the-rise.htm

"Internet time" in OECD Observer No 268 June 2008, see https://oe.cd/1iX https:// oe.cd/1ix

Wyckoff, Andy (2016), "Digital economy: Why a brighter future could be in our pocket", in OECD Observer Yearbook, https://oe.cd/obs/2sy https://oe.cd/obs/2sy

psilanti, D (1999), “A borderless world: the OECD Ottawa Ministerial Conference”, at www.emeraldinsight.com at www.emeraldinsight.com 